Spain, and Ukraine. Comparative analysis is also provided as well as a detailed review of the literature on this topic.

-The Global Future of Higher Education and the Academic Profession. Edited by Philip G. Altbach, Gregory Androushchak, Yaroslav Kuzminov, Maria Yudkevich, and Liz A. Reisberg. Basingstoke, UK: Palgrave Macmillan, 20I5. 264 pp. $\$ 40(\mathrm{pb})$. Note that this is a newly released paperback edition of our 20г2 volume. Analyses of the challenges facing universities in the BRIC countries with special reference to the academic profession.

- Global Opportunities and Challenges for Higher Education Leaders: Briefs on Key Themes. Edited by Laura E. Rumb- ley, Robin Matross Helms, Patti McGill Peterson, and Philip G. Altbach. Rotterdam, Netherlands: Sense, 20I4. 25I pp. $\$ 45$ (pb). Short essays aimed at higher education leaders are provided on 4 key themes-global engagement, China, India, and the "Southern Cone" of Latin America. The essays focus on the current challenges and opportunities of universities in these countries, the role of internationalization, the development of partnerships, and related themes. While the essays were written to inform American higher education leaders, they are globally relevant.

\title{
News of the Center
}

We are in the process of welcoming Hans de Wit as the new Center director-see an article about Hans elsewhere in this issue. He will be joining the Boston College faculty in September and will teach a course on internationalization in the fall semester. Among our many plans is to build a master's program focused on international higher education as part of the Boston College higher education administration graduate program.

Philip G. Altbach remains a research professor at Boston College and takes the title of Founding Director of CIHE. He will remain active in the Center's work and will continue to edit International Higher Education.

On April 23, 20I5 Philip G. Altbach (as keynote) and Laura E. Rumbley (as panelist) participated in an international higher education seminar at Northeastern University. On April 29, 20I5 the Center co-sponsored an event at Harvard University on "Global assessment of higher education learning outcomes." Convened by Manja Klemenčič, the session speakers included Dirk van Damme (OECD), Henry Rosovsky (Harvard University), Marjik van der Wende (former dean of Amsterdam University College), and Philip G. Altbach. Also in April, Altbach spoke at a workshop for all of the rectors of universities in Saudi Arabia. He continues to serve on the planning committee of the International Conference on Higher Education for the Saudi Ministry of Higher Education.

In May, Philip G. Altbach, along with Kara Godwin, CIHE visiting scholar, will participate in a conference on liberal arts in Shanghai, China, sponsored by the Harvard China Fund and Amsterdam University College.

The Center has recently copublished, with the American Council on Education's Center for Internationalization and Global Engagement, number 5 in the series "International Briefs for Higher Education Leaders." This Brief focused on the subject of international joint- and dual-degree programs.
The Center is pleased to announce that its extensive 2014 publication, Higher Education: A Worldwide Inventory of Research Centers, Academic Programs, and Journals (3rd edition), is now freely available for download from the CIHE Web site. Work on the Center's small follow-up survey from that inventory-focused explicitly on the profiles and activities of those research centers around the world that are in some way undertaking research specifically in the field of "international higher education"-is moving forward, under the direction of Center associate director Laura E. Rumbley and doctoral research assistants Ariane de Gayardon and Georgiana Mihut.

Laura E. Rumbley, Philip G. Altbach, and Hans de Wit are all active in the May conference of NAFSA: Association of International Educators, which takes place in Boston. They will be speaking at several sessions. CIHE will host a small invitational seminar at Boston College, as well, to mark the 2oth anniversary of the Center's establishment. Featured speakers include Eva Egron-Polak (International Association of Universities) and Francisco Marmolejo (World Bank).

CIHE will again be collaborating with the Centre for Internationalisation of Higher Education (CHEI) — based at the Università Cattolica del Sacro Cuore in Milan, Italy-to produce a special issue of International Higher Education focused on the theme of internationalization. All inquiries about this special issue (including deadlines, article requirements, and style guide information) should be directed to Fiona Hunter, CHEI Research Associate, at chei@unicatt.it.

We warmly welcome summer 2015 visiting scholars Daniel Kontowski (University of Warsaw, Poland) and Armağan Erdoğan (Social Sciences University of Ankara, Turkey). 